that the prisoner had recently suffered misfortunes, and it was contended that although he could not be considered insane, yet these misfortunes, occurring in a man of excitable nervous disposition, had to some extent unhinged his mind, and rendered him incapable of appreciating fully the circumstances. In summing up, the judge agreed that the crime was so outrageous that it took a great deal to make them believe that a sane man would commit it; nevertheless, he scouted the idea that the prisoner was insane, and from the very full report it seems as if he did not appreciate, or paid no attention to, the contention of the defence, that, under stress of calamity, a man's mind might be brought into such a condition that he was partially irresponsible. The jury found the prisoner guilty, but recom. mended him to mercy on account of his age and previous good character. He was sentenced, nothwithstanding, to twenty years penal servitude.-Manchester Assizes (Mr. Justice Phillimore).-Manchester Guardian, November 16th.

\title{
Reg v. Dowling and Dowling.
}

Fredk. Dowling, xt. $6_{3}$, tailor, and Charlotte Dowling, æt. 67 , his wife, were charged with the manslaughter of their son. The deceased was of weak intellect, bedridden and blind. He lived with his parents in one room, which was in a condition described as terrible. It was not suggested that he was starved, but he suffered from severe bedsores, and the prisoners were charged with culpable neglect in not calling in medical assistance. Guilty, but recommended to mercy on account of their age. Fifteen months hard labour.-Winchester Assizes (Mr. Justice Kennedy).-Times, November 24th.

Reg. v. Holbrook.

Maurice Holbrook, æt. 42, cabman, was indicted for the wilful murder of Percy Hayton. The prisoner went to the police station and gave himself up for having killed the boy, and search being made, the body of the boy, xt. 9, was found in a field with his throat cut. The prisoner did not know the boy or his parents, and there was no discernible motive for the crime. It was suggested by the prosecution that the prisoner was insane, and Dr. Worthington, superintendent of the Hants County Asylum, who had examined the prisoner on behalf of the Treasury, gave his opinion that the prisoner, who was an epileptic, was not responsible for his acts when he committed the crime. Guilty, but insane.-Winchester Assizes (Mr. Justice Kennedy).-Times, November 24th

This case is rather important. The prisoner had left the workhouse only three days before, and we may therefore presume that his mental state did not then present sufficient ground for his transfer to the County Asylum. He was epileptic, and committed an apparently motiveless crime, but this crime was not done during post-epileptic automatism, for he himself was the first person to give notice of the murder. It was an instance of the insane and apparently motiveless acts of violence which are not unfrequently committed by epileptics during their inter-paroxysmal intervals, instances of which have been before recorded in this column. That similar acts are committed by epileptics during post-paroxysmal automatism is well known, but it is important to recognise that these acts are not necessarily confined to nor distinctive of the post-epileptic automatism, but may be committed by epileptics at times which appear to be independent of the fits.

$$
\text { Reg. v. Nyland. }
$$

John Nyland, æt. 42, journalist, was indicted for causing to be received by Archibald Johnstone a letter threatening to murder him. Before the prisoner was called upon to plead, the issue was raised whether he was fit to plead to the indictment. Mr. C. Read, M.R.C.S., stated that in his opinion the prisoner was of unsound mind, did not realise the nature of the charge against him, and was not in a condition of mind to give proper and reasonable instructions for his defence. This witness was cross-examined at some length and with ability by the prisoner. Dr. Scott stated that he considered the prisoner insane. The judge pointed out that the articles in the Daily Telegraph, which had provoked the prisoner into writing the letter, were in bad taste and cruel, but that there was such an enormous disproportion between the offensive nature of the articles and the threatened retaliation, that the jury might very well say that a man who could not appreciate that 
disproportion could hardly be in a fit state of mind to conduct his defence or take his trial. The jury found that the prisoner was unfit to plead, and that the articles which had provoked him were quite uncalled for. In this verdict the judge expressed his full concurrence.-Central Criminal Court (Mr. Justice Wills).Times, November 25th.

An uunsual instance of procedure. The preliminary issue whether a prisoner is fit to plead is not usually raised unless the prisoner is very deeply insane, either extremely demented or wildly maniacal. In this case the prisoner had sufficient ability to cross-examine with considerable acumen. The case is noteworthy from the formal ruling of the judge that a great disproportion between provocation and retaliation is itself a sufficient proof of insanity to exonerate a prisoner from being dealt with as an ordinary criminal. This is a doctrine which medical men have often brought forward in courts of law, and which the judicial mind has always shown the utmost reluctance to admit. It is important to have a case on record in which the doctrine has been explicitly accepted by the bench. Whether it was worth while to invoke the machinery of the law to protect a journalist from the natural consequences of jeering at a lunatic, a thing that no decently conducted asylum attendant would think of doing, is a matter of opinion.

$$
\text { Reg. v. King. }
$$

Philip King was charged with the murder of his mother-in-law, his wife, and his two children. Prisoner had murdered the two women in a very brutal manner, and the two children were found in the same room, the one smothered, and the other dead of cold and starvation. The plea of insanity was not raised, and the case is mentioned here mainly to show that a very brutal and multiple murder does not necessarily imply insanity on the part of the murderer.-Dublin Express, December $13^{\text {th }}$ and $14^{\text {th. }}$

$$
\text { Reg. v. Schneider. }
$$

Prisoner, a butcher, æt. 36, was charged with the wilful murder of Conrad Berndt. The unfortunate Berndt was murdered and placed in an oven, in which his remains were partially consumed. Counsel for the defence suggested insanity, but called no evidence, and on the part of the prosecution the evidence of sanity was strong.-Guilty.-C. C. C. (Mr. Justice Hawkins).-Times, December 14th and 15 th.

$$
\text { Reg. v. Lawley. }
$$

William Lawley, 55, tradesman, was charged with the murder of his wife. In August, 1897, he became insane, violently attacked his wife and was sent to Coton Hill Asylum. In May, 1898, he was liberated on trial and lived with relatives and in charge of an attendant in Manchester. On July 2nd the attendant was dispensed with. On July 16 th he left Manchester, went to his wife's home at Much Wenlock and murdered her. Without hearing counsel for the defence the jury found the prisoner guilty but insane.-Shrewsbury Assizes (Mr. Justice Ridley).Times, November ist.

Illustrates the great difficulty in deciding when a lunatic is sufficiently recovered to be at large.

$$
\text { Curtis v. Callingham and others. }
$$

A probate case. The will was dated July, 1894, and it was shown that the testatrix had suffered from delirium tremens in 1878, and that in her later years she had been scarcely ever sober. One or two witnesses had seen her sober occasionally, and the witnesses to the will stated that she was sober when she executed the will, which was upheld by the jury.-Probate Division (Mr. Justice Barnes).Times, January 26th.

The evidence of incapacity was very strong indeed, but the trial had the usual result.

Hodson and Another v. Park.

The defendant presented a petition for a reception order with respect to his wife, the daughter of the plaintiffs, and in the statement of particulars attached to 